\title{
Tracheostomy in COVID-19 Pandemic Era
}

\author{
Young Ju Jin ${ }^{1}$ (D) and Seong Dong $\mathrm{Kim}^{2}$ \\ ${ }^{1}$ Department of Otorhinolaryngology-Head and Neck Surgery, Wonkwang University Hospital, \\ Wonkwang University College of Medicine, Iksan; and \\ ${ }^{2}$ Department of Otorhinolaryngology-Head and Neck Surgery, National Medical Center, Seoul, Korea \\ 코로나바이러스감염증-19 대유행 시대에 기관절개술 시 고려사항과 표준 술기 \\ 진영주 ${ }^{1} \cdot$ 김성동 $^{2}$ \\ ${ }^{1}$ 원광대학교 의과대학 이비인후과학교실, ${ }^{2}$ 국립의료원 이비인후과
}

\author{
Received July 1,2021 \\ Revised August 2, 2021 \\ Accepted August 4, 2021 \\ Address for correspondence \\ Young Ju Jin, MD, PhD \\ Department of Otorhinolaryngology- \\ Head and Neck Surgery, \\ Wonkwang University Hospital, \\ Wonkwang University \\ College of Medicine, \\ 895 Muwang-ro, Iksan 54538, Korea \\ Tel $+82-63-859-1445$ \\ Fax $+82-63-859-1440$ \\ E-mail chindol@hanmail.net
}

The outbreak of new coronavirus (COVID-19) has emerged as the cause of a severe acute respiratory. The COVID-19 pandemic led to an unexpected increase in the number of patients who are critically ill and required mechanical ventilation for active respiratory support. Tracheostomy is a common surgical procedure performed on patient to provide long-term ventilator support or to manage upper airway obstruction. It could be a critical role in the management of COVID-19 patients. Insertion of a tracheal cannula has become a viable alternative to prolonged endotracheal intubation, with the benefits of decreased airway resistance, improved patient comfort, reduced need for sedation, easier sputum removal. While these interventions could be necessary to provide adequate care, they require special precautions to minimize occupational risk. Because the spread of COVID-19 happened by aerosol and fine droplets, medical staffs are in direct danger of occupational exposure while caring for these patients. The purpose of this article is to review the preoperative preparation and tracheostomy guidelines related to COVID-19 pandemic spread.

Korean J Otorhinolaryngol-Head Neck Surg 2021;64(9):613-8

Keywords Aerosols; COVID-19; Mechanical ventilation; Personal protective equipment; Tracheostomy.

\section{서 론}

코로나바이러스감염증-19 (COVID 19)는 새로운 코로나 바이러스인 SARS-CoV-2에 의해 발생하는 호흡기 감염병으 로, 2019년 12월 중국 우한에서 처음 보고된 이후 현재까지 전 세계에 확산되었다. 가장 흔한 증상은 발열, 마른기침, 피 로이며, 그 외 후각 및 미각 소실, 근육통, 인후통, 콧물, 코막 힘, 두통, 설사 등 다양한 증상이 나타날 수 있다.1) 대부분의 환자들(80\%)은 특별한 치료없이 회복되나 5 명 중 1 명은 중증 으로 진행될 수 있고, 특히 고령자나 고혈압, 심폐질환, 당뇨병,

This is an Open Access article distributed under the terms of the Creative Commons Attribution Non-Commercial License (https://creativecommons.org/licenses/by-nc/4.0) which permits unrestricted non-commercial use, distribution, and reproduction in any medium, provided the original work is properly cited.
암과 같은 기저질환이 있는 환자가 중증으로 진행될 가능성 이 높다. ${ }^{2} 2000$ 년 이후 우리나라를 비롯한 세계적인 바이러스 질환의 대유행은 약 5-6년 주기로 지속적으로 발생하고 있다 (Table 1). 한편, 2021년 6월 21일 현재 COVID-19의 국내 총 확진자수는 151506명이며, 사망자수는 2004명(1.3\%)이고, ${ }^{1)}$ 세계 총 확진자수는 178118597 명이며, 사망자수는 3864180 명(2.2\%)이다. ${ }^{2)}$ 이들 중 중증 환자들은 중환자실에 입원하여 기도삽관하에 기계 호흡기를 이용한 호흡 보조를 필요로 하 게 된다.

기관절개술은 이비인후과 영역에서 흔히 행해지는 수술이 며, 주로 장시간 기계호흡 보조가 필요하거나 상기도 폐쇄를 치료해야 하는 환자에게 시행된다. 의료기술의 발달과 함께, 더 오랜 시간 동안 기계호흡을 해야 하는 환자의 수는 점점 
Korean J Otorhinolaryngol-Head Neck Surg I 2021;64(9):613-8

Table 1. Number of domestic infected and death patients in serial virus era

\begin{tabular}{|c|c|c|c|}
\hline Year & Virus name & $\begin{array}{l}\text { Number of domestic } \\
\text { infected patients }\end{array}$ & $\begin{array}{c}\text { Number of domestic } \\
\text { death patients }\end{array}$ \\
\hline 2003 & Severe Acute Respiratory Syndrome Corona virus (SARS-CoV-1) & 3 (probable) & 0 \\
\hline 2009 & Influenza HINI & 763759 & 270 \\
\hline 2015 & Middle East Respiratory Syndrome Coronavirus (MERS-CoV) & 186 & 38 \\
\hline $2019.12-2021.06 .21$ & Corona Virus Disease-2019 (COVID-19, SARS-CoV-2) & 151506 & 2004 \\
\hline
\end{tabular}

증가하였다. 기관절개술의 가장 흔한 적응증은 급성 호흡 부 전이며, 이외 기도 확보가 필요한 신경학적 질환, 악안면 외상 에 의한 상기도 폐쇄, 구인두 염증, 성대마비와 두경부 암의 원인이 보고되었다. ${ }^{3)}$ 장기간 기관 내 삽관은 구인두 감염원을 정상적인 후두 방어 메커니즘이 없는 기관, 기관지 및 폐로 직 접적으로 전파함으로써 인공호흡기 관련된 폐렴)을 유발할 수 있고, 이 외에도 축농증, ${ }^{5}$ 연하장애,6) 성문하 및 기관 협착(6) 을 발생시킬 수 있다고 보고되었다. 그러므로 기관절개술을 통한 캐뉼라의 삽입은 장기간 기관 내 삽관이 필요한 환자에 게 실행 가능한 대안이 되었는데, 환자의 기도 저항 감소, 편 안함 향상, 진정약물투여 감소, 가래 제거를 더 쉽게 하며, 대 화 가능, 구강을 통한 음식 섭취 가능, 보행 가능과 같은 많은 장점들이 있다. 그 중 특히, 기관 캐뉼라 삽입의 가장 중요한 이점은 기계 호흡(인공호흡기) 보조를 안전하게 중단할 수 있 다는 것이다. ${ }^{78)}$ 이전의 연구들에 의하면 중환자실 입원 환자 들의 $10 \%-24 \%$ 는 입원 기간 동안 기관절개술을 시행한다고 보고되었는데, ${ }^{9,10)}$ 중환자실에서 기관절개술을 시행한 환자의 30 일 이내 사망률은 $25 \%-46 \%$ 로 비교적 높은 것으로 보고 되었다. ${ }^{11,12)}$ 기관절개술은 대표적으로 에어로졸을 발생시킬 수 있는 수술이고, 시행하는 의료인력이 직접적으로 에어로 졸에 노출될 수 있다는 점 때문에 우리나라 현실에 맞는 가 이드라인이 필요하다.

이 논문에서는 COVID-19와 같이 전염력 강한 바이러스 대유행 시대에 감염 및 중증 악화로 오랜 시간 기계 호흡 보 조를 받아야 하는 환자들에게 기관절개술 고려 시, 시행 시 기, 수술 전 준비 사항 및 핵심 프로시저에 대해 정리해 보고 자 한다.

\section{본 론}

\section{기관절개술 시행 시기}

기관절개술 시행 시기에 대해서는 두 가지 논란이 있는데, 기관절개술 시기에 관한 논란과, 기관절개술 전 바이러스 음 전이 여부에 대한 것이다. COVID-19 대유행 이전에도 시기 에 대한 논란이 존재했으며, 일부 논문에서는 조기 기관절개 술(기도 삽관 후 10 일 이내, 혹은 14 일 이내) 시행 시 질병률 (morbidity)과 사망률(mortality)에 이득이 있다고 보고하였 으나, ${ }^{13,14)}$ 다른 논문들에서는 조기 기관절개술(논문에 따라 기도 삽관 후 7일 이내, 혹은 14 일 이내)은 장기 사망률을 줄 이지 않고, ${ }^{15,16)}$ 후두 기관 협착의 위험성을 유의미하게 감소 시키지 않으나, ${ }^{17}$ 중환자실 입원 기간, 기계 호흡 기간, 인공호 흡기 관련된 폐렴(ventilator associated pneumonia)을 감소 시킨다고 보고하였다. ${ }^{15,16,18,19)}$

COVID-19 대유행 이전에는 이른 혹은 지연된 기관절개술 로 인해 환자에게 끼치는 위해성에 대한 고려가 주된 관심 사 항이었는데, 바이러스 대유행 이후에는 의료종사자의 안전에 대한 고려가 추가되었다. 대유행 초기에는 감염자의 호흡기 에서 나온 바이러스가 주로 비말의 상태로 공기중에 분사되 어, 비교적 짧은 거리를 이동해( $2 \mathrm{~m}$ 이내) 수시간-수일 동안 활성화된 상태로 머물러 전염력이 증가될 수 있다고 보고되 었으나, 이후에는 바이러스가 비말보다 더 크기가 작은 에어 로졸 $(\operatorname{size}<5 \mu \mathrm{m})$ 로 공기 중에 분사되기 때문에 안정적으로 오랜 시간 공기 중에 전염력을 유지할 수 있어서 전파 위험성 을 더 증가시킨다고 보고되었다. 한 연구에서 SARS-CoV-2 바이러스는 공기 중에 머무는 3시간 동안 감염성 있는 바이 러스 농도는 103.5에서 102.7 (TCID 50 per liter)로 약간 감소 하였으며, 특히 플라스틱이나 스테인레스 스틸 위에서는 72 시 간 이상 생존 가능한 바이러스 상태로 검출되었다. ${ }^{20)}$ 한편, 기 관절개술은 대표적으로 에어로졸을 발생시키는 술기로, ${ }^{21)}$ 이 전 SARS-CoV-1 대유행 시 환자에게 에어로졸을 발생시키 는 술기를 행한 의료종사자를 대상으로 한 연구에서 기관절 개술을 시행한 의료진은 그렇지 않은 의료진에 비해 odds ratio 4.15 (confidence interval 1.5-11.5, $p<0.01$ )로 유의미 하게 감염률이 높았음을 발표하였다. ${ }^{22)}$

다음 이슈는 COVID-19 감염 환자에게 기관절개술 전 COVID-19 바이러스의 음전이 여부의 필요성에 대한 논란 이다. COVID-19 대유행의 초기에 나온 연구에서는, COVID-19 양성 환자는 검사상 음성이 될 때까지 기관절개술을 연기하고, 특히 가음성의 가능성도 있기 때문에 48시간 후에 두 번째 검사를 시행하여 음성이 진단되었을 때 기관절개술 을 시행하라고 제시하였다. ${ }^{23)}$ 하지만 이후 대부분의 논문에서 는 COVID-19 음전이 여부는 중요하지 않으며, 기관절개술이 
필요한 환자는 중환자실 입원 이후 최소 14일 즈음 후에 시행 하도록 제시하였다. ${ }^{24-28)}$ 기관절개술 시행 전 SARS-CoV-2 항 원 검사의 음전이 여부는 중요하지 않으며, 감염 후 시간의 경 과에 따라 SARS CoV-2 RNA PCR 검사상의 항원양은 점점 줄어들고, 항바이러스 항체는 점차 증가하므로, 기관절개술은 중환자실에 입원하여 기관 삽관 후 10-14일 후에, 혹은 증상 발생 후 20-24일 후에 고려하라고 제시하였다. ${ }^{25)} \mathrm{McGrath}$ 등 ${ }^{26)}$ 이 발표한 리뷰 논문에 의하면 인두에서 검출되는 viral RNA 양은 증상이 발생한 첫 주에 최고조를 이루며, 혈청 항 체는 감염자의 절반에서 증상 발현 7일 후에 검출되기 시작 하였으며 14 일까지 거의 모든 감염자에게서 검출되었다. 따라 서, 기관절개술은 중환자실에 입원한지 10-21일 후에, 증상이 발생한지 16-30일 후에 시행하도록 제시되었다. 한편 Chen 등 ${ }^{29)}$ 은 22 명 환자의 인두, 가래, 대변 검체 545 개를 검사해보 니, 인두 검체에서 바이러스에 대한 RT- $\mathrm{qPCR}$ 검사가 음성 으로 진단된 후에도, 가래나 대변 검체는 각각 39 일, 13 일 더 양성으로 검출되어, 인두 검체에서 더 이상 바이러스가 검출 되지 않아 음전이로 진단된 환자도 다른 검체에서 여전히 양 성일 수 있어서, 음성의 기준에 대한 의구심을 불러 일으켰 다. ${ }^{29)}$ 한편, 2000년부터 2020년 4월까지 SARS, MERS, COVID-19 관련 논문을 리뷰한 연구에 의하면, 에어로졸 발생 술기 동안 측정 가능한 바이러스 양과 전염률과의 연관성과, 기관절개술과 관련된 감염률도 아직 보고되지는 않았지만, 기관절개 수술 전 두번의 테스트가 의료진에게 더 안전하며, 다만 바이러스 대유행 시대에 의료 자원이 부족하므로, 기관 삽관 최소 14 일 후에 기관절개술을 고려하는 것이 가장 합당 하다고 발표하였다. ${ }^{24}$

\section{수술적 기관절개술 혹은 경피적 확장 기관절개술}

어느 술기가 더 우위에 있거나 아래에 있지 않으며, 각 병 원의 경험과 의료 자원에 따라 결정한다. $24,26,30)$

\section{기관절개술이 시행되는 장소}

기관절개술은 중환자실 내의 음압병실에서 시행되어야 하
며, 음압병실의 사용이 어려운 경우에는 high-efficiency particulate air (HEPA) 필터를 사용한다. ${ }^{23,25,27)}$

\section{수술적 기관절개술 시 필요한 인력}

기관절개술에 필요한 인력은 최소한으로 하며 마취과 의사 1 명, 기관절개술 수술의사 1 명, 수술 보조의사 1 명, 수술 필드 내 간호사 1명, 수술 필드에 들어와 있지는 않지만 음압실 내 에서 도와줄 간호사 1 명으로 최소화하며, 수술은 경력이 많 은 의사가 시행해야 한다.

\section{개인보호장구}

에어로졸 노출 위험이 있는 경우에는 중앙방역대책본부 매뉴얼에 따라 개인보호구를 착용하는데(Table 2), 에어로졸 이 생성되는 처치는 기관 삽관, 심폐소생술, 기관지내시경술, 기도분비물흡인, 기관 관리, 사체 부검, 비침습적 양압환기, 분무 요법, 가래 배출 유도의 처치, 상황 행위를 말한다. ${ }^{31}$

\section{수술적 기관절개술 시 핵심 준비 사항}

COVID-19 환자의 수술을 위해서 중환자실 내의 음압실 에 입실 시 개인 보호장구를 갖추고 들어가야 하기 때문에 (Fig. 1), 수술 중 필요한 것이 생겼을 때 즉시 조달 받기에 어 려움이 있다. 특히 기관절개술을 중환자실 내에서 자주 시행 하던 병원이 아닌 경우에는 일반적인 수술을 위해 필요한 도 구들 외에, 음압실 입실 전, 혹은 음압실에서 수술을 시작하 기 전에 한 번 더 챙겨야 할 물품들은 아래와 같다.

1) 전등: 개인보호장구를 입으면 헤드램프의 착용이 어려 울 수 있고, 중환자실에서는 수술장의 조명을 기대할 수 없 기 때문에 이동 가능한 밝은 전등이 필요하다(Fig. 1B).

2) 전기 소작 기구(Bovie, Bipolar) 작동 확인: 중환자실에 서 자주 사용하는 도구가 아니기 때문에, 기관절개술을 위해 절개 후 출혈 발생으로 전기 소작 기구를 사용하려고 할 때, 작동이 잘 안되는 경우가 매우 흔하므로 미리 확인해야 한다.

3) 메탈 석션 팁(Metal suction tip): 기도가 열린 후 캐뉼 라를 넣기 위해 구강을 통해 삽관된 관을 뺄 때 많은 분비물

Table 2. 코로나바이러스감염증-19 대응상황별 개인보호구 권장범위 ${ }^{31)}$

\begin{tabular}{|c|c|c|c|c|c|c|c|c|}
\hline \multirow{4}{*}{ 구 분 } & \multirow{4}{*}{ 상황, 행위 } & \multicolumn{7}{|c|}{ 개인보호구 } \\
\hline & & \multicolumn{3}{|c|}{ 호흡기 보호 } & \multicolumn{3}{|c|}{ 전신 보호 } & \multirow{3}{*}{$\begin{array}{c}\text { 눈 보호 } \\
\text { 고글(또는 } \\
\text { 안면 보호구) }\end{array}$} \\
\hline & & 수술용 & KF 94 동급의 & 전동식 호흡기 & 이히요 작가 & 일회용 방수성 & 전신보호복 & \\
\hline & & 마스크 & 호흡기 보호구 & 보호구 & 릴외굥 상밥 & 긴팔 가운 & (덧신 포함) & \\
\hline \multirow[t]{2}{*}{ 선별진료소 } & 선별진료소 접수, 안내 & \multicolumn{3}{|c|}{0} & O & \multicolumn{2}{|l|}{0} & \\
\hline & 선별진료소 진료, 간호 & \multicolumn{3}{|c|}{ O } & ○ & \multicolumn{2}{|c|}{ O (선택사용 가능) } & ○ \\
\hline \multirow[t]{2}{*}{ 진 료 } & $\begin{array}{l}\text { 확신/의심환자 병실출입, } \\
\text { 진료, 간호 등 }\end{array}$ & \multicolumn{3}{|c|}{ O } & O & \multicolumn{2}{|c|}{ O (선택사용 가능) } & ○ \\
\hline & 에어로졸 생성 처치 & \multicolumn{3}{|c|}{ O (선택사용 가능) } & O & \multicolumn{2}{|c|}{ O (선택사용 가능) } & O \\
\hline
\end{tabular}



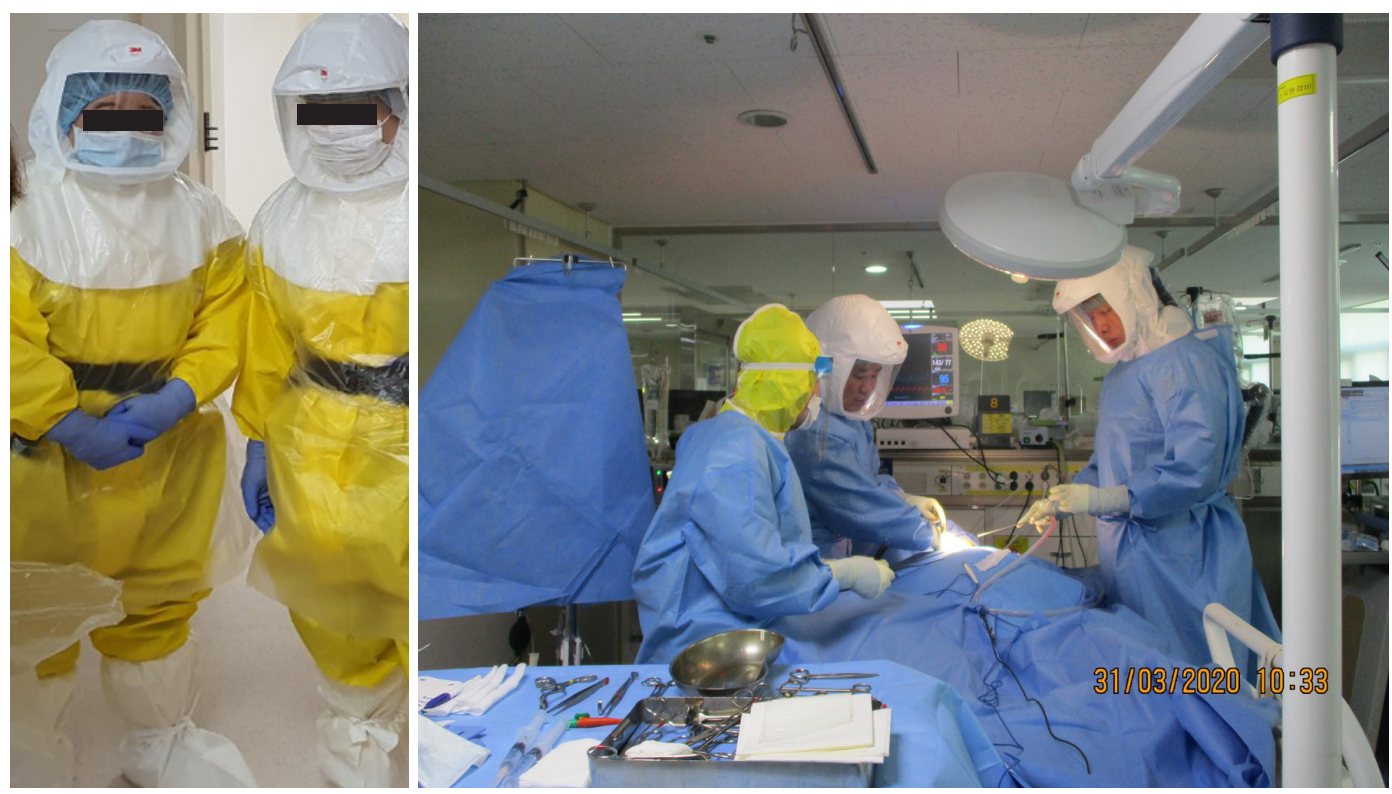

Fig. 1. Staffs wear PPE with powered air purifying respirator (PAPR) to enter the negative pressure room in the intensive care unit for tracheostomy. In operation field, all staffs wear surgical gown over PPE. PPE, personal protective equipment.

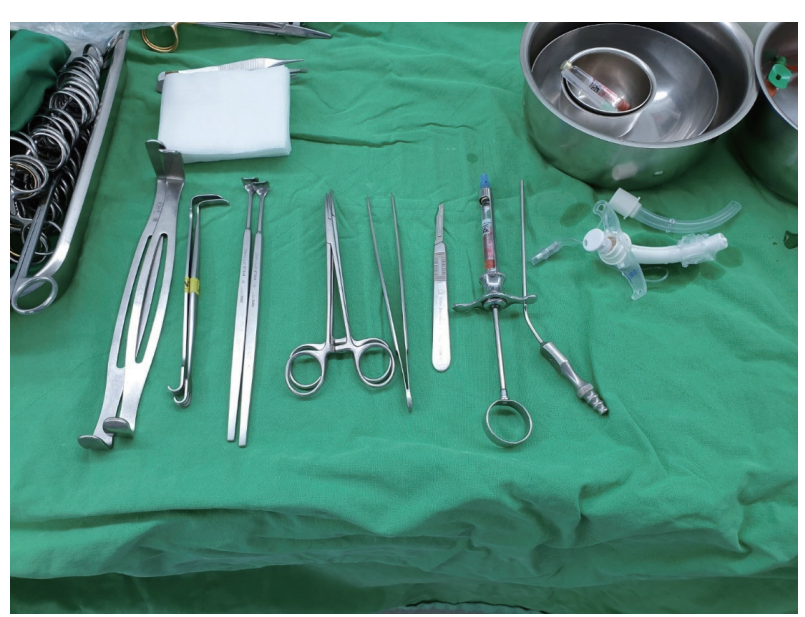

Fig. 2. Basic surgical instruments for tracheostomy and non-fenestrated cuffed couble lumen cannula.

이 열려진 기관지로 나오는 경우가 흔하므로 메탈 석션 팁을 준비해 놓는다. 수술장에서 수술 시에는 쉽게 구할 수 있는 물품이지만 중환자실에 준비된 수술도구 세트에는 없는 경 우가 흔하다.

4) Non-fenestrated cuffed tracheostomy cannula. 특히 double lumen cannula가 매우 유용하다(Fig. 2).

5) 기관절개술을 위해 기관지를 노출시킬 때, self retaining mastoid retractor가 유용하게 사용될 수 있다.

6) 이외 기본적인 수술도구(Fig. 2).

\section{기관절개술 술기 $23,24,27,32,33)$}

1) 환자를 천정을 보고 누운 자세로 위치시키며 어깨 베개
를 사용하여 경부를 신장시킨다.

2) 수술 중 기침 반응을 최소화하기 위하여 신경 근육 차 단 약제를 사용하여 완전히 마비시킨다.

3) 기관 삽관 튜브의 커프를 예상하는 기관창보다 더 아랫 쪽에 위치하도록 밀어 넣고 에어로졸 등의 누출을 막기 위해 튜브 커프를 최대한 팽창시킨다.

4) 기관창을 내기 전 최소한 5 분 동안 산소포화도를 $100 \%$ 로 유지한다.

5) 기관창을 내고, 캐뉼라를 넣기 위한 준비를 위해 기관 삽관 튜브를 뺄 때 기계호흡을 중단시킨 뒤 행한다.

6) 기관창 캐뉼라를 넣고 즉시 커프를 팽창시킨다.

7) 클램프된 기관 내 튜브를 제거한다.

8) 기관창 캐뉼라는 폐쇄회로와 연결한다.

9) End tidal $\mathrm{CO} 2$ 를 체크해 캐뉼라가 기도 내로 잘 들어 갔는지 확인한다.

10) Viral filter나 가습필터(Heat and Moisture Exchanger [HME] filter)를 기관창 캐뉼라에 연결한다.

\section{시술 후 고려사항}

수술 후 기관절개부위 관련 처치들은 에어로졸을 발생시 킬 수 있기 때문에 최소한으로 한다. 내관 교체 빈도를 최소 화하며, 커프는 잘 유지되도록 체크 한다. 기관절개관 교체는 COVID-19 음전이 된 후 시행하도록 한다. ${ }^{26)}$ 


\section{결 론}

COVID-19 감염 환자에게 행하는 기관절개술은 에어로 졸을 통한 감염 전파의 위험성 때문에 의료진에게 부담이 된 다. 환자가 중환자실 입실 약 14 일 후에 의료진이 적절한 개 인보호장구를 잘 갖추고 수술하는 것이 감염의 위험성을 낮 추는 핵심으로 사료되며, 수술 전후 주의사항과 준비사항을 잘 숙지하여 환자와 의료진 모두에게 안전한 기관절개술이 되어야 한다.

\section{Acknowledgments}

This work was supported in part by a research grant (NRF-2019R1G1A1-099842) from the National Research Foundation (NRF) of Korea.

\section{Author Contribution}

Conceptualization: Young Ju Jin, Seong Dong Kim. Data curation: Young Ju Jin. Formal analysis: Young Ju Jin. Funding acquisition: Young Ju Jin. Investigation: Young Ju Jin, Seong Dong Kim. Methodology: Young Ju Jin. Project administration: Young Ju Jin. Resources: Young Ju Jin. Supervision: Young Ju Jin. Validation: Young Ju Jin. Visualization: Young Ju Jin. Writing — original draft: Young Ju Jin, Seong Dong Kim. Writing — review \& editing: Young Ju Jin, Seong Dong Kim.

\section{ORCID}

Young Ju Jin

https://orcid.org/0000-0001-7428-5123

\section{REFERENCES}

1) Korea Disease Control and Prevention Agency. Coronavirus Disease-19, Republic of Korea [Internet]. Sejong: The Ministry of Health and Welfare; 2020 [cited 2021 Jun 21]. Available from: URL: http://ncov.mohw.go.kr/.

2) World Health Organization. Q\&As on COVID-19 and related health topics [Internet]. Geneva: World Health Organization; 2021 [cited 2021 Jun 21]. Available from: URL: https://www.who.int/ emergencies/diseases/novel-coronavirus-2019/question-andanswers-hub/.

3) Cheung NH, Napolitano LM. Tracheostomy: Epidemiology, indications, timing, technique, and outcomes. Respir Care 2014; 59(6):895-915; discussion 916-9.

4) Rello J, Ollendorf DA, Oster G, Vera-Llonch M, Bellm L, Redman $\mathrm{R}$, et al. Epidemiology and outcomes of ventilator-associated pneumonia in a large US database. Chest 2002;122(6):2115-21.

5) Metheny NA, Hinyard LJ, Mohammed KA. Incidence of sinusitis associated with endotracheal and nasogastric tubes: NIS database. Am J Crit Care 2018;27(1):24-31.

6) Skoretz SA, Flowers HL, Martino R. The incidence of dysphagia following endotracheal intubation: A systematic review. Chest 2010;137(3):665-73

7) De Leyn P, Bedert L, Delcroix M, Depuydt P, Lauwers G, Sokolov Y, et al. Tracheotomy: Clinical review and guidelines. Eur J Cardiothorac Surg 2007;32(3):412-21.

8) Engels PT, Bagshaw SM, Meier M, Brindley PG. Tracheostomy: From insertion to decannulation. Can J Surg 2009;52(5):427-33.

9) Freeman BD, Borecki IB, Coopersmith CM, Buchman TG. Relationship between tracheostomy timing and duration of mechanical ventilation in critically ill patients. Crit Care Med
2005;33(11):2513-20

10) Frutos-Vivar F, Esteban A, Apezteguía C, Anzueto A, Nightingale $\mathrm{P}$, González $\mathrm{M}$, et al. Outcome of mechanically ventilated patients who require a tracheostomy. Crit Care Med 2005;33(2):290-8.

11) Kejner AE, Castellanos PF, Rosenthal EL, Hawn MT. All-cause mortality after tracheostomy at a tertiary care hospital over a 10-month period. Otolaryngol Head Neck Surg 2012;146(6):918-22.

12) Young D, Harrison DA, Cuthbertson BH, Rowan K; TracMan Collaborators. Effect of early vs late tracheostomy placement on survival in patients receiving mechanical ventilation: The TracMan randomized trial. JAMA 2013;309(20):2121-9.

13) Rumbak MJ, Newton M, Truncale T, Schwartz SW, Adams JW, Hazard PB. A prospective, randomized, study comparing early percutaneous dilational tracheotomy to prolonged translaryngeal intubation (delayed tracheotomy) in critically ill medical patients. Crit Care Med 2004;32(8):1689-94.

14) Olton S, Hariharan S, Chen D. Outcome evaluation of patients requiring tracheostomy in an intensive care unit in Trinidad. West Indian Med J 2009;58(2):173-8.

15) Chorath K, Hoang A, Rajasekaran K, Moreira A. Association of early vs late tracheostomy placement with pneumonia and ventilator days in critically ill patients: A meta-analysis. JAMA Otolaryngol Head Neck Surg 2021;147(5):450-9.

16) Affronti A, Casali F, Eusebi P, Todisco C, Volpi F, Beato V, et al. Early versus late tracheostomy in cardiac surgical patients: A 12year single center experience. J Cardiothorac Vasc Anesth 2019; 33(1):82-90.

17) Curry SD, Rowan PJ. Laryngotracheal stenosis in early vs late tracheostomy: A systematic review. Otolaryngol Head Neck Surg 2020;162(2):160-7.

18) Arabi YM, Alhashemi JA, Tamim HM, Esteban A, Haddad SH, Dawood A, et al. The impact of time to tracheostomy on mechanical ventilation duration, length of stay, and mortality in intensive care unit patients. J Crit Care 2009;24(3):435-40.

19) Andriolo BN, Andriolo RB, Saconato H, Atallah ÁN, Valente O. Early versus late tracheostomy for critically ill patients. Cochrane Database Syst Rev 2015;(1):CD007271.

20) van Doremalen N, Bushmaker T, Morris DH, Holbrook MG, Gamble A, Williamson BN, et al. Aerosol and surface stability of SARS-CoV-2 as compared with SARS-CoV-1. N Engl J Med 2020; 382(16):1564-7.

21) Brewster DJ, Chrimes N, Do TB, Fraser K, Groombridge CJ, Higgs A, et al. Consensus statement: Safe Airway Society principles of airway management and tracheal intubation specific to the COVID-19 adult patient group. Med J Aust 2020;212(10):472-81.

22) Chen WQ, Ling WH, Lu CY, Hao YT, Lin ZN, Ling L, et al. Which preventive measures might protect health care workers from SARS? BMC Public Health 2009;9:81.

23) Heyd CP, Desiato VM, Nguyen SA, O'Rourke AK, Clemmens CS, Awad MI, et al. Tracheostomy protocols during COVID-19 pandemic. Head Neck 2020;42(6):1297-302.

24) Takhar A, Walker A, Tricklebank S, Wyncoll D, Hart N, Jacob T, et al. Recommendation of a practical guideline for safe tracheostomy during the COVID-19 pandemic. Eur Arch Otorhinolaryngol 2020; 277(8):2173-84

25) McGrath BA, Ashby N, Birchall M, Dean P, Doherty C, Ferguson $\mathrm{K}$, et al. Multidisciplinary guidance for safe tracheostomy care during the COVID-19 pandemic: The NHS National Patient Safety Improvement Programme (NatPatSIP). Anaesthesia 2020;75(12): 1659-70.

26) McGrath BA, Brenner MJ, Warrillow SJ, Pandian V, Arora A, Cameron TS, et al. Tracheostomy in the COVID-19 era: Global and multidisciplinary guidance. Lancet Respir Med 2020;8(7):717-25.

27) Volo T, Stritoni P, Battel I, Zennaro B, Lazzari F, Bellin M, et al. 
Elective tracheostomy during COVID-19 outbreak: To whom, when, how? Early experience from Venice, Italy. Eur Arch Otorhinolaryngol 2021;278(3):781-9.

28) David AP, Russell MD, El-Sayed IH, Russell MS. Tracheostomy guidelines developed at a large academic medical center during the COVID-19 pandemic. Head Neck 2020;42(6):1291-6.

29) Chen C, Gao G, Xu Y, Pu L, Wang Q, Wang L, et al. SARS-CoV-2positive sputum and feces after conversion of pharyngeal samples in patients With COVID-19. Ann Intern Med 2020;172(12):832-4.

30) Schultz MJ, Ahmed HY, Shrestha GS, West TE, Papali A; 'COVID-LMIC Task Force' and the 'Mahidol-Oxford Research Unit' (MORU). Pragmatic recommendations for tracheostomy, discharge, and rehabilitation measures in hospitalized patients recovering from severe COVID-19 in low- and middle-income countries. Am J Trop Med Hyg 2021;104(3 Suppl):110-9.
31) The Ministry of Health and Welfare. COVID-19 pandemic: Guide on infective medical center [Internet]. Sejong: The Ministry of Health and Welfare; 2021 [cited 2021 Jul 30]. Available from: URL: http://ncov.mohw.go.kr/upload/viewer/skin/doc.html? $\mathrm{fn}=1617239052038 \_20210401100412 . p d f \& r s=/$ upload/viewer/ result/202109/.

32) Broderick D, Kyzas P, Sanders K, Sawyerr A, Katre C, Vassiliou L. Surgical tracheostomies in Covid-19 patients: Important considerations and the "5Ts" of safety. Br J Oral Maxillofac Surg 2020;58(5):585-9.

33) Pichi B, Mazzola F, Bonsembiante A, Petruzzi G, Zocchi J, Moretto S, et al. CORONA-steps for tracheotomy in COVID-19 patients: A staff-safe method for airway management. Oral Oncol 2020;105:104682.

\section{정답 및 해설}

해 설 참고 문헌: 대한이비인후과학회. 이비인후과학:두경부외과학. 개정판. 서울: 일조각;2009. p.1564. 